\title{
Antioxidant Activities of Ginseng Seeds Treated by Autoclaving
}

\author{
Hye-Min Bae', Sung-Soo Kim ${ }^{1}$, Chang-Won Cho ${ }^{1}$, Deok-Chun Yang ${ }^{2}$, Sung Kwon Ko ${ }^{3}$, \\ and Kyung-Tack Kim ${ }^{1^{*}}$ \\ ${ }^{1}$ Processing Technology Research Group, Korea Food Research Institute, Seongnam 463-746, Korea \\ ${ }^{2}$ Department of Oriental Medicinal Materials and Processing, College of Life Science, Kyung Hee University, Suwon 449-701, Korea \\ ${ }^{3}$ Department of Oriental Medical Food \& Nutrition, Semyung University, Jecheon 390-711, Korea
}

\begin{abstract}
Ginseng seeds were treated with different autoclaving temperatures and autoclaving times, and extracted with $80 \%$ methanol to measure changes in antioxidant activity. The antioxidant activity of ginseng seeds treated by autoclaving was measured by 1,1-diphenyl-2-picrylhydrazyl radical scavenging activity, 2,2'-aziono-bis(3-ethylbenzthiazoline)-6-sulfonic acid radical scavenging activity, superoxide dismutase SOD-like activity, ferric reducing antioxidant power (FRAP), and total phenolic compound content. As autoclaving temperature and time were increased, the $L$ lightness value decreased and the redness value tended to increase. Total phenolic compound content was about three times higher in ginseng seeds treated with autoclaving at $130^{\circ} \mathrm{C}$ than in ginseng seeds that were not treated. DPPH radical scavenging activity and ABTS radical scavenging activity increased as autoclaving temperature and time were increased. In particular, when the concentration was $100 \mathrm{ppm}$, the ABTS radical scavenging activity was $91.80 \%$ in ginseng seeds treated by autoclaving at $130^{\circ} \mathrm{C}$, which was the highest antioxidant activity. FRAP and SOD-like antioxidant activity tended to increase significantly as autoclaving temperature and time were increased.
\end{abstract}

Keywords: Panax ginseng, Ginseng seed, Autoclaving, Antioxidant activities

\section{INTRODUCTION}

Ginseng (Panax ginseng Meyer) is a perennial plant in the Araliaceae family and has been used as an herbal medicine ingredient since ancient times [1]. Ginseng contains carbohydrates $(60 \%$ to $70 \%)$, nitrogen compounds ( $12 \%$ to $16 \%$ ), saponin ( $3 \%$ to $6 \%)$, fat-soluble compounds ( $1 \%$ to $2 \%$ ), minerals ( $4 \%$ to $6 \%$ ), and vitamins $(0.05 \%)$ [2]. Physiological activities of ginseng include a nourishing and strengthening effect, improved reproductive function, anti-hypertension and anti-arteriosclerosis, an anemia-treating effect, a glucose metabolism and diabetes improving effect, anticancer, hepatic function improving effect, hangover relieving effect, parasite infection prevention, and analgesic and anti-inflammatory

(c) This is an Open Access article distributed under the terms of the Creative Commons Attribution Non-Commercial License (http://creativecommons.org/licenses/by-nc/3.0/) which permits unrestricted non-commercial use, distribution, and reproduction in any medium, provided the original work is properly cited. effects, which have been studied through systematic pharmacological approaches.

Red ginseng is manufactured by autoclaving, drying, and shaping of fresh ginseng, during which the heat treatment causes various chemical changes such as changes in saponin and amino acid content, browning, and starch gelatinization to increase the pharmacological effect of fresh and white ginseng [3]. The direction of ginseng research has shifted from pharmacological efficacy evaluations to efficacy improvement development to meet consumer needs. Additionally, ginseng studies have reported component changes due to puffing, fermentation, or high-temperature high-pressure treatment and the

Received 22 Jun. 2012, Revised 14 Aug. 2012, Accepted 28 Aug. 2012

*Corresponding author

E-mail: tack@kfri.re.kr

Tel: +82-31-780-9096, Fax: +82-2-31-709-9876 
effect on antioxidant activity [4-8]. Furthermore, studies on the changes of various ginseng components following heat treatment have been conducted. In addition to red ginseng, the development of new types of products has been attempted by applying various processing methods [9-13].

While ginseng seed has only been used as a means to cultivate ginseng, recent studies show that ginseng berries contain active ingredients similar to those in ginseng roots $[14,15]$. However, most studies on ginseng seeds are insufficient. Studies that have analyzed ginsenoside content of ginseng seeds, compared the characteristics of fatty acids in ginseng seed oil from different countries, analyzed phytosterol in American ginseng seed [16-18], and investigated skin-related phototoxicity of a ginseng seed extract seemed adequate [19]. These studies mainly included phytosterol content of ginseng seed or oil analyses of seeds under different cultivation environments, but studies on physiological activities are insufficient because they focused on roots alone. Thus, this study was performed to investigate the changes in physicochemical characteristics and antioxidant activity in ginseng seeds under different autoclaving conditions.

\section{MATERIALS AND METHODS}

\section{Preparation of the ginseng seed extract}

A $100 \mathrm{~g}$ sample of 4-year-old ginseng seeds, purchased at Geumsan market in Korea in July 2011, was autoclaved using high-temperature high-pressure equipment (Red Ginseng High Temperature Reactor; Mega Science, Seoul, Korea). The autoclaving conditions widely and commercially used for autoclaving red ginseng were employed: $3 \mathrm{~h}$ at $95^{\circ} \mathrm{C}, 30 \mathrm{~min}$ at $115^{\circ} \mathrm{C}, 60 \mathrm{~min}$ at $115^{\circ} \mathrm{C}$, $90 \mathrm{~min}$ at $130^{\circ} \mathrm{C}$, and $120 \mathrm{~min}$ at $130^{\circ} \mathrm{C}$. After the heat treatment, the samples were hot-air dried.

A $2 \mathrm{~g}$ sample of ginseng seeds treated by autoclaving was mixed with $50 \mathrm{~mL}$ of $80 \%$ methanol and pulverized, and then the soluble components were extracted by attaching a reflux condenser in a hot water bath. The extract was filtered onto filter paper (Whatman no.2), vacuum-concentrated, dissolved in $30 \mathrm{~mL}$ of dimethyl sulfoxide (DMSO), and filtered through a $0.45-\mu \mathrm{m}$ membrane filter to obtain samples. All experiments were conducted in triplicate.

\section{Color}

Chromaticity of the ginseng seeds was measured by a spectrocolorimeter (Color QUEST; Hunter Laboratories, Reston, VA, USA), calibrated with a standard white board (lightness $[L]=92.68$, redness $[a]=0.81$, yellowness $[b]=0.86)$. Chromaticity was calculated as mean values using the formula $\Delta \mathrm{E}=\sqrt{ }(\Delta L)^{2}+(\Delta a)^{2}+(\Delta b)^{2}$ after measuring $L, a$, and $b$ (Hunter Laboratories) in triplicate.

\section{Total phenolic compound contents}

Total phenolic compound contents was colorimetrically determined according to the Folin-Denis method [20]. A sample of $100 \mu \mathrm{L}$ of ginseng seed extract treated under the different heat treatment conditions was mixed with $5 \mathrm{~mL}$ distilled water, and $1 \mathrm{~mL}$ of Folin reagent was added and mixed with $1.5 \mathrm{~mL}$ of $20 \% \mathrm{Na}_{2} \mathrm{CO}_{3}$ solution. The solution was left at room temperature for $2 \mathrm{~h}$, and the absorbance was measured at $765 \mathrm{~nm}$. Total phenolic content was expressed as gallic acid equivalents.

\section{1,1-Diphenyl-2-picrylhydrazyl radical scavenging activity}

1,1-Diphenyl-2-picrylhydrazyl (DPPH) radical scavenging activity was measured by modifying the method of Blois [21]. A $0.4 \mathrm{~mL}$ aliquot of ginseng seed extract diluted in DMSO was added to $2.8 \mathrm{~mL}$ of ethanol and 0.8 $\mathrm{mL}$ of $4 \times 10^{-4} \mathrm{M}$ DPPH (Sigma-Aldrich Inc., St. Louis, MO, USA) solution was dissolved in ethanol, added, and vortexed for $10 \mathrm{~s}$. This solution was left at room temperature for $10 \mathrm{~min}$ and the absorbance was measured at 517 $\mathrm{nm}$. DPPH radical scavenging activity was expressed as a percentage by measuring absorbance of the sample treatment groups and the negative control group.

\section{Ferric reducing antioxidant power}

The ferric reducing antioxidant power (FRAP) assay was used to measure radical reducing activity by modifying the method of Hassas-Roudsari [22]. A stock solution was prepared by dissolving $10 \mathrm{mM}$ TPTZ solution and $20 \mathrm{mM} \mathrm{FeCl}{ }_{3} \cdot 6 \mathrm{H}_{2} \mathrm{O}$ solution in $0.3 \mathrm{M}$ sodium acetate buffer (pH 3.6) and $40 \mathrm{mM} \mathrm{HCl}$. Fresh working solution (25 mL acetate buffer, $2.5 \mathrm{~mL}$ TPTZ solution, and $2.5 \mathrm{~mL}$ $\mathrm{FeCl}_{3} \cdot 6 \mathrm{H}_{2} \mathrm{O}$ solution) was prepared at $37^{\circ} \mathrm{C}$ before the experiment. A $0.3 \mathrm{~mL}$ aliquot of the sample extract was mixed with $2.7 \mathrm{~mL}$ FRAP solution and left in a dark place for $30 \mathrm{~min}$, and the absorbance was measured at $593 \mathrm{~nm}$.

\section{2,2'-Aziono-bis(3-ethylbenzthiazoline)-6-sulfonic acid radical scavenging activity}

2,2'-Aziono-bis(3-ethylbenzthiazoline)-6-sulfonic acid (ABTS) radical scavenging activity was measured using the method of Van den Berg et al. [23]. A solution of $2.5 \mathrm{mM}$ ABTS (Wako Pure Chemical, Osaka, Japan)

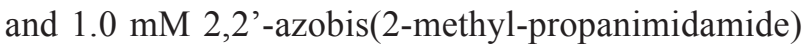


dihydrochloride (Wako Pure Chemical) were mixed in $0.1 \mathrm{M}$ phosphate buffered saline ( $\mathrm{pH}$ 7.4), left to react in the dark at $68^{\circ} \mathrm{C}$ for $12 \mathrm{~min}$, and then quickly cooled to prepare the $\mathrm{ABTS}^{+}$solution. A $20 \mu \mathrm{L}$ sample of ginseng seed extract was mixed with $980 \mu \mathrm{L}$ of $\mathrm{ABTS}^{+}$solution and reacted at $37^{\circ} \mathrm{C}$ in a water bath for $10 \mathrm{~min}$, and the absorbance was measured at $734 \mathrm{~nm}$. The results are expressed as a percentage by measuring absorbance of the sample treatment groups and the negative control group.

\section{Antioxidant enzyme activity}

SOD-like activity in relation to the elimination of reactive oxygen species was measured. Ginseng seed extract was added and reacted using a SOD assay kit-WST (Dojindo Lab, Gaithersburg, MD, USA), and the absorbance was measured at $450 \mathrm{~nm}$.

\section{Statistical analysis}

Results of the sensory evaluation were analyzed using the SPSS ver. 10.0 (SPSS Inc., Chicago, IL, USA) program. Duncan's multiple range test was applied at a significance level of $0.05(p<0.05)$.

\section{RESURTS AND DISCUSSION}

\section{Colorimetric measurements}

The chromaticity of the autoclaved ginseng seed powder is shown in Table 1. The $L$-value for lightness was 48.26 in untreated ginseng seeds, 46.36 in ginseng seeds autoclaved at $95^{\circ} \mathrm{C}$ for $180 \mathrm{~min}, 43.77$ and 42.19 at $115^{\circ} \mathrm{C}$ for 30 and $60 \mathrm{~min}$, and 29.2 and 28.77 at $130^{\circ} \mathrm{C}$ for 90 and $120 \mathrm{~min}$, respectively. The lightness of ginseng seeds treated with varying temperatures and times was significantly lower compared to the control group not treated with autoclaving. The $a$-value for redness was 6.21 in untreated ginseng seeds, 6.89 in ginseng seeds autoclaved at $115^{\circ} \mathrm{C}$ for $60 \mathrm{~min}$, and 10.01 in seeds autoclaved at $130^{\circ} \mathrm{C}$ for $120 \mathrm{~min}$, indicating that redness increased significantly with the increase in temperature and time. The $b$-value for yellowness was 23.98 in untreated ginseng seeds, 23.49 in ginseng seeds autoclaved at $95^{\circ} \mathrm{C}$ for $180 \mathrm{~min}, 23.24$ and 23.12 in ginseng seeds autoclaved at $115^{\circ} \mathrm{C}$ for 30 and $60 \mathrm{~min}$, respectively, and 18.04 and 16.27 in ginseng seeds autoclaved at $130^{\circ} \mathrm{C}$ for 90 and $120 \mathrm{~min}$, respectively reflecting decreased yellowness compared to that in untreated ginseng seeds. Browning of the melanoidine pigment due to the amino-carbonyl reaction was observed when ginseng is autoclaved. Thus, ginseng seeds also show color changes due to a browning reaction during the autoclaving treatment [24].
Table 1. Chromaticity of ginseng seed extract

\begin{tabular}{cccc}
\hline \multirow{2}{*}{ Treatments } & \multicolumn{3}{c}{ Hunter color values } \\
\cline { 2 - 4 } & $L$-value & $a$-value & $b$-value \\
\hline Control & $48.26 \pm 0.58^{\mathrm{e}}$ & $6.21 \pm 0.22^{\mathrm{a}}$ & $23.98 \pm 0.53^{\mathrm{d}}$ \\
1 & $46.36 \pm 0.14^{\mathrm{d}}$ & $7.27 \pm 0.15^{\mathrm{c}}$ & $23.49 \pm 0.02^{\mathrm{d}}$ \\
2 & $43.77 \pm 0.83^{\mathrm{c}}$ & $6.69 \pm 0.37^{\mathrm{b}}$ & $23.24 \pm 0.52^{\mathrm{c}}$ \\
3 & $42.19 \pm 0.41^{\mathrm{b}}$ & $6.89 \pm 0.26^{\mathrm{bc}}$ & $23.12 \pm 0.53^{\mathrm{c}}$ \\
4 & $29.20 \pm 0.83^{\mathrm{a}}$ & $8.56 \pm 0.32^{\mathrm{d}}$ & $18.04 \pm 0.77^{\mathrm{b}}$ \\
5 & $28.77 \pm 0.24^{\mathrm{a}}$ & $10.01 \pm 0.36^{\mathrm{e}}$ & $16.27 \pm 0.47^{\mathrm{a}}$ \\
\hline
\end{tabular}

Control, no treatment; 1 , autoclaving treatment at $95^{\circ} \mathrm{C}$ for $180 \mathrm{~min} ; 2$, autoclaving treatment at $115^{\circ} \mathrm{C}$ for $30 \mathrm{~min} ; 3$, autoclaving treatment at $115^{\circ} \mathrm{C}$ for $60 \mathrm{~min} ; 4$, autoclaving treatment at $130^{\circ} \mathrm{C}$ for $90 \mathrm{~min} ; 5$, autoclaving treatment at $130^{\circ} \mathrm{C}$ for $120 \mathrm{~min}$.

Each value represents the mean and standard deviation for triplicate experiments. Different letters between values in a row indicate a significant difference at $\alpha=0.05$ by Duncan's multiple range test.

Table 2. Total phenolic compound content

\begin{tabular}{cc}
\hline Treatments & Total phenolic compound (\%) \\
\hline Control & $0.31 \pm 0.00$ \\
1 & $0.38 \pm 0.04$ \\
2 & $0.39 \pm 0.04$ \\
3 & $0.88 \pm 0.02$ \\
4 & $1.02 \pm 0.04$ \\
5 & $0.33 \pm 0.03$ \\
\hline
\end{tabular}

Control, no treatment; 1 , autoclaving treatment at $95^{\circ} \mathrm{C}$ for $180 \mathrm{~min} ; 2$, autoclaving treatment at $115^{\circ} \mathrm{C}$ for $30 \mathrm{~min} ; 3$, autoclaving treatment at $115^{\circ} \mathrm{C}$ for $60 \mathrm{~min} ; 4$, autoclaving treatment at $130^{\circ} \mathrm{C}$ for $90 \mathrm{~min} ; 5$, autoclaving treatment at $130^{\circ} \mathrm{C}$ for $120 \mathrm{~min}$.

Each value is the mean and standard deviation for triplicate experiments. Different letters in a row indicate a significant difference at $\alpha=0.05$ by Duncan's multiple range test.

\section{Total phenolic compound contents}

The total phenolic compound contents of the autoclaved ginseng seeds is shown in Table 2. As the autoclaving temperature and time were increased, total phenolic compound contents of the ginseng seeds increased. That is, total phenolic compound contents of untreated ginseng seeds was $0.31 \%$, that of ginseng seed autoclaved at $95^{\circ} \mathrm{C}$ for $180 \mathrm{~min}$ was $0.33 \%$, and that at $115^{\circ} \mathrm{C}$ for 30 and 60 min was $0.38 \%$ and $0.3 \%$, respectively. In particular, the total phenolic compound contents in ginseng seeds autoclaved at $130^{\circ} \mathrm{C}$ for 90 and 120 min were $0.88 \%$ and $1.02 \%$, respectively, which was about three times higher compared to that of untreated ginseng seeds. According to a study by Yang et al. [25], polyphenol contents increased as treatment temperature increased during high-temperature high-pressure heat treatment of ginseng, which was similar to the results of our study. The increase in total polyphenols is thought to result from the transformation of bound to free polyphenols due to the 


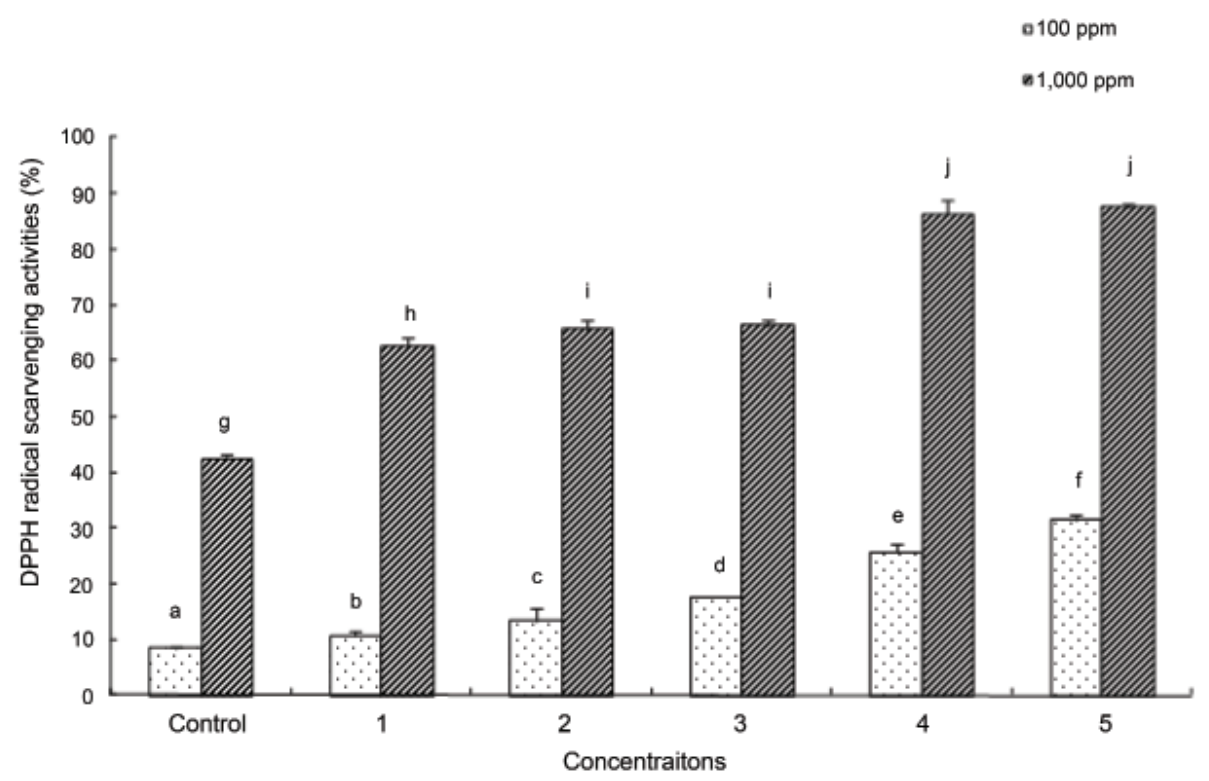

Fig. 1. 1,1-Diphenyl-2-picrylhydrazyl (DPPH) radical scavenging activity of ginseng seed extract. Control, no treatment; 1 , autoclaving treatment at $95^{\circ} \mathrm{C}$ for $180 \mathrm{~min} ; 2$, autoclaving treatment at $115^{\circ} \mathrm{C}$ for $30 \mathrm{~min} ; 3$, autoclaving treatment at $115^{\circ} \mathrm{C}$ for $60 \mathrm{~min} ; 4$, autoclaving treatment at $130^{\circ} \mathrm{C}$ for $90 \mathrm{~min} ; 5$, autoclaving treatment at $130^{\circ} \mathrm{C}$ for $120 \mathrm{~min}$. Each bar represents the mean and standard deviation for triplicate experiments. Different letters over a bar indicate a significant difference at $\alpha=0.05$ by Duncan's multiple range test.

high-temperature high-pressure heat treatment and the transformation of high-molecular weight phenolic compounds to low-molecular weight phenolic compounds or the production of new phenolic compounds.

\section{1,1-Diphenyl-2-picrylhydrazyl radical scavenging activity}

The most commonly used measurement of antioxidant activity is the indirect method of DPPH free radical scavenging activity. Therefore, reduction of DPPH during the reaction indicates that the free radical scavenging reaction is in progress, which can be used to estimate the degree of suppression of the early lipid peroxidation reaction [26]. The results of DPPH radical scavenging activity measurement in ginseng seed extracts treated with varying autoclaving temperatures and times are shown in Fig. 1. DPPH radical scavenging activity was higher in autoclave-treated ginseng seeds compared to that in untreated ginseng seeds. In addition, as autoclaving temperature was increased and autoclaving time was longer, DPPH radical scavenging activity increased significantly. In particular, DPPH radical scavenging activity was the highest in ginseng seeds autoclaved at $130^{\circ} \mathrm{C}$, and the activity was higher in ginseng seeds treated at $115^{\circ} \mathrm{C}$ for $30 \mathrm{~min}$ compared to those treated at $95^{\circ} \mathrm{C}$ for $180 \mathrm{~min}$. These results are similar to those observed in a study by Yang et al. [25] in which the antioxidant effect was examined based on a ginseng heat treatment. In that study, total phenolic compounds and antioxidant activity increased as temperature increased suggesting that autoclaving temperature was more influential than time. This was probably caused by increased antioxidant activity due to the reducing power of phenolic compounds.

\section{2,2'-Aziono-bis(3-ethylbenzthiazoline)-6-sulfonic acid radical scavenging activity}

The ABTS method is a method for measuring antioxidant activity using discoloration of blue-green color unique to radicals when the ABTS ${ }^{*}{ }^{+}$is generated during a reaction with potassium persulfate and eliminated by antioxidant substances in the sample. The measurement of antioxidant activity by the ABTS method is different from that of the DPPH method in that ABTS eliminates positive-ion radicals, and the capability of radical elimination in the two methods is different because the degree of binding between the two substrates and reactants are different [27].

The results of ABTS radical scavenging activity in the ginseng seed extracts exposed to varying autoclaving temperatures and times are shown in Fig. 2. The activity of the $100 \mathrm{ppm}$ extract was $29.8 \%$ in untreated ginseng seeds, $54.01 \%$ in ginseng seeds autoclaved at $95^{\circ} \mathrm{C}$ for 3 h, $56.95 \%$ at $115^{\circ} \mathrm{C}$ for $30 \mathrm{~min}, 61.84 \%$ at $115^{\circ} \mathrm{C}$ for 60 $\min , 84.18 \%$ at $130^{\circ} \mathrm{C}$ for $90 \mathrm{~min}$, and $91.08 \%$ at $130^{\circ} \mathrm{C}$ 


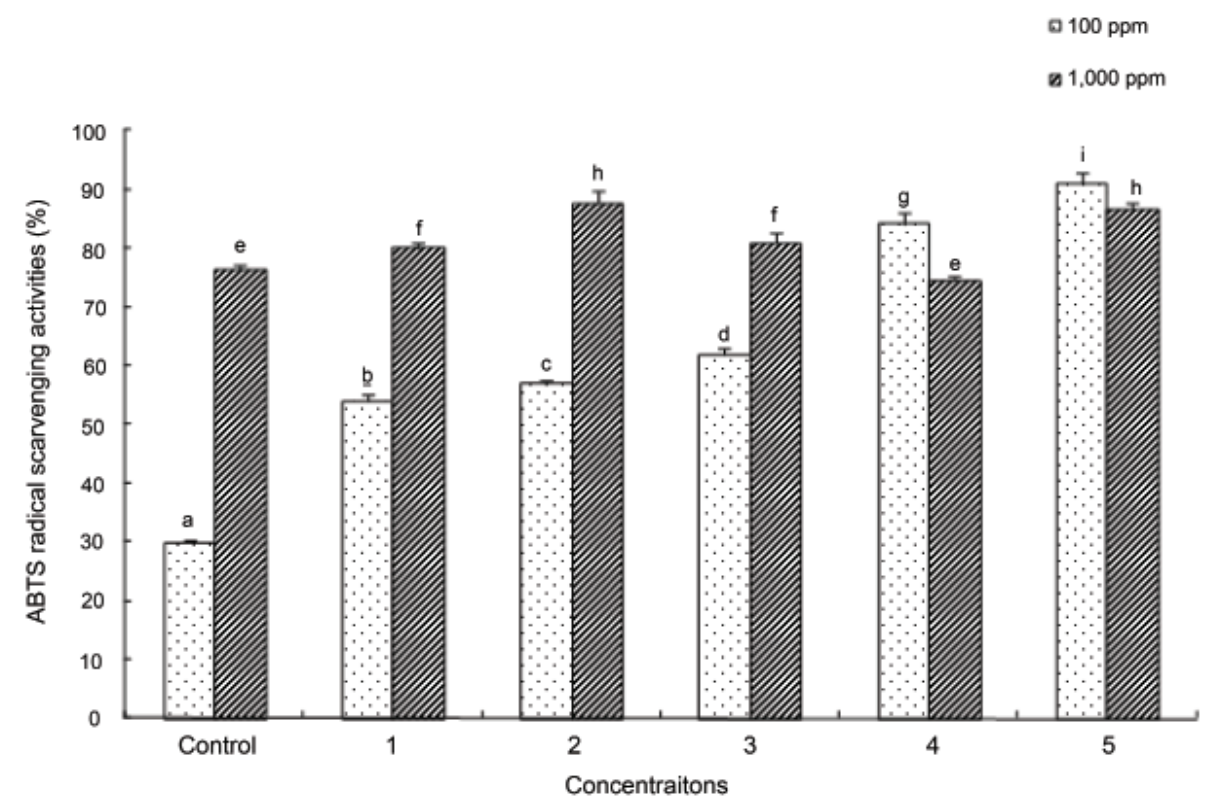

Fig. 2. 2,2'-Aziono-bis(3-ethylbenzthiazoline)-6-sulfonic acid (ABTS) radical scavenging activity of ginseng seed extract. Control, no treatment; 1 , autoclaving treatment at $95^{\circ} \mathrm{C}$ for $180 \mathrm{~min} ; 2$, autoclaving treatment at $115^{\circ} \mathrm{C}$ for $30 \mathrm{~min} ; 3$, autoclaving treatment at $115^{\circ} \mathrm{C}$ for $60 \mathrm{~min} ; 4$, autoclaving treatment at $130^{\circ} \mathrm{C}$ for $90 \mathrm{~min} ; 5$, autoclaving treatment at $130^{\circ} \mathrm{C}$ for $120 \mathrm{~min}$. Each bar represents the mean and standard deviation for triplicate experiments. Different letters over a bar indicate a significant difference at $\alpha=0.05$ by Duncan's multiple range test.

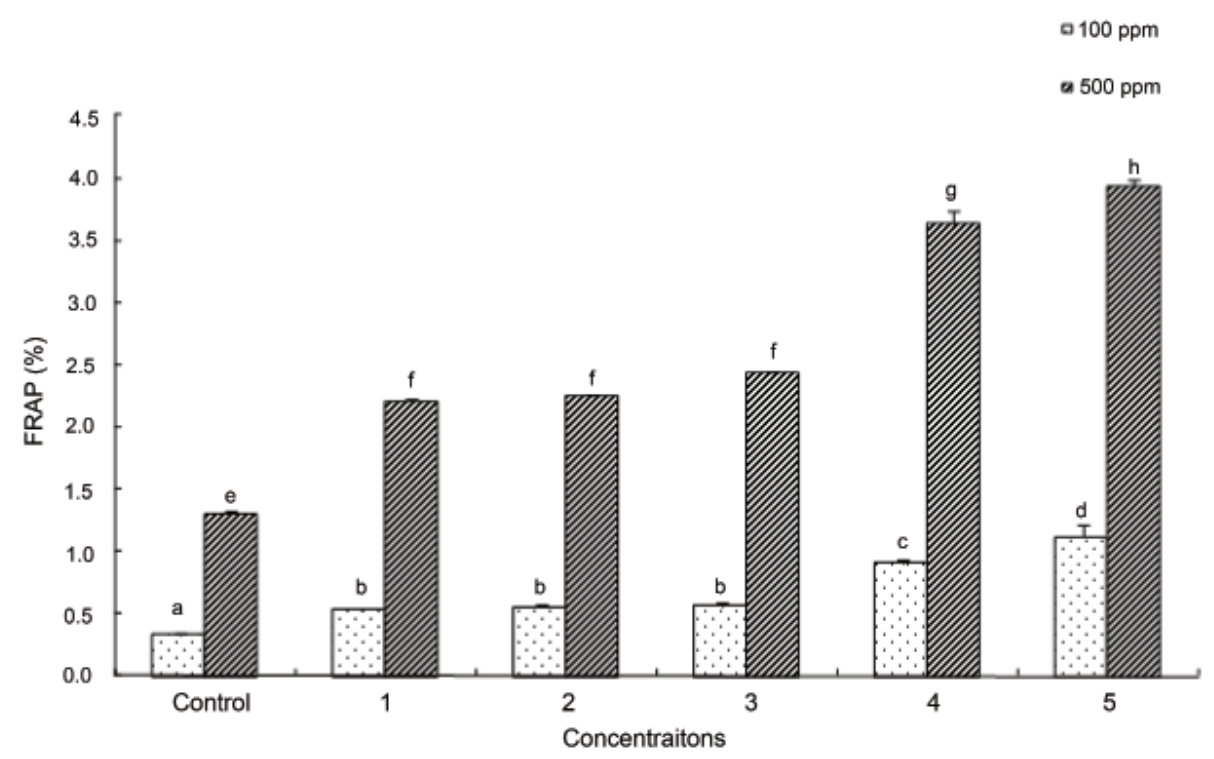

Fig. 3. Ferric reducing antioxidant power (FRAP) of ginseng seed extract. Control, no treatment; 1 , autoclaving treatment at $95^{\circ} \mathrm{C}$ for $180 \mathrm{~min}$; 2, autoclaving treatment at $115^{\circ} \mathrm{C}$ for $30 \mathrm{~min} ; 3$, autoclaving treatment at $115^{\circ} \mathrm{C}$ for $60 \mathrm{~min} ; 4$, autoclaving treatment at $130^{\circ} \mathrm{C}$ for 90 min, 5 , autoclaving treatment at $130^{\circ} \mathrm{C}$ for $120 \mathrm{~min}$. Each bar represents the mean and standard deviation for triplicate experiments. Different letters over a bar indicate a significant difference at $\alpha=0.05$ by Duncan's multiple range test.

for $120 \mathrm{~min}$, showing that the activity increased significantly as autoclaving time and autoclaving temperature were increased $(p<0.05)$. However, ABTS radical scavenging activity was not different between untreated and treated ginseng seeds for the $1,000 \mathrm{ppm}$ samples, and the activity of ginseng seeds treated at $115^{\circ} \mathrm{C}$ was slightly higher than those treated at $130^{\circ} \mathrm{C}$. However, ginseng seeds treated by autoclaving showed an increased tendency for ABTS radical scavenging activity compared to that in the untreated groups.

\section{Ferric reducing antioxidant power antioxidant ac- tivity}

The FRAP method is used to measure the ability to 


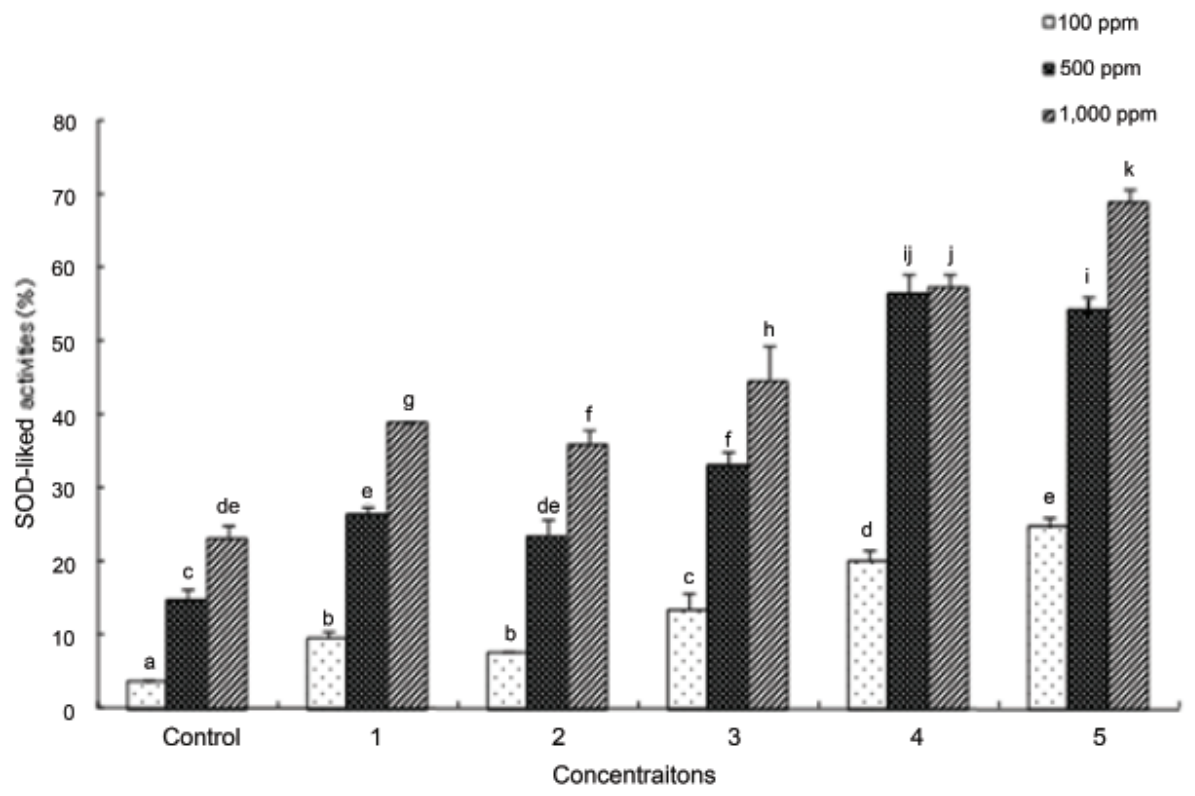

Fig. 4. Superoxide anion radical scavenging effect of ginseng seed extract. Control, no treatment; 1 , autoclaving treatment at $95^{\circ} \mathrm{C}$ for 180 min; 2, autoclaving treatment at $115^{\circ} \mathrm{C}$ for $30 \mathrm{~min} ; 3$, autoclaving treatment at $115^{\circ} \mathrm{C}$ for $60 \mathrm{~min} ; 4$, autoclaving treatment at $130^{\circ} \mathrm{C}$ for 90 min; 5 , autoclaving treatment at $130^{\circ} \mathrm{C}$ for $120 \mathrm{~min}$. Each bar represents the mean and standard deviation for triplicate experiments. Different letters over a bar indicate a significant difference at $\alpha=0.05$ by Duncan's multiple range test. SOD, superoxide dismutase.

reduce $\mathrm{Fe}^{3+}$ to $\mathrm{Fe}^{2+}$ by a reducing agent in samples or extracts [22]. The results of FRAP activity are shown in Fig. 3. In the $100 \mathrm{ppm}$ ginseng seed extract, the absorbance was 0.33 in the untreated ginseng seeds, 0.53 in ginseng seeds autoclaved at $95^{\circ} \mathrm{C}$ for $180 \mathrm{~min}, 0.55$ and 0.56 at $115^{\circ} \mathrm{C}$ for 30 and $60 \mathrm{~min}$, respectively, and 0.91 and 1.12 at $130^{\circ} \mathrm{C}$ for 90 and $120 \mathrm{~min}$, respectively. The FRAP activity, as with ABTS radical scavenging activity, showed higher absorbance in autoclaved ginseng seeds than that in untreated ginseng seeds, and absorbance increased significantly as autoclaving time and temperature increased $(p<0.05)$. As reported in a study by Kim et al. [28] in which antioxidant activity increased during repeated steam-drying during the manufacturing of black ginseng, antioxidant activity increased when ginseng seeds were autoclaved at high temperature rather than low temperature. It was confirmed that the antioxidant activity was higher in ginseng seeds autoclaved at $130^{\circ} \mathrm{C}$ for $90 \mathrm{~min}$ compared to those treated at $95^{\circ} \mathrm{C}$ for $3 \mathrm{~h}$, which is the commercially used condition for manufacturing red ginseng.

\section{Antioxidant enzyme activity}

SOD plays a role suppressing peroxides, which are produced from free radicals such as the superoxide anion radical, hydroxy radical, peroxyl radical, and nitric oxide radical as well as singlet oxygen, ozone, and peroxides due to reactive oxygen. The SOD-like activity measure- ments in ginseng seed autoclaved under varying temperatures and times are shown in Fig. 4. Enzyme activity at 100,500 , and $1,000 \mathrm{ppm}$ of seed extract was $3.71 \%$, $14.98 \%$, and $23.10 \%$, respectively, in untreated ginseng seeds and $24.78 \%, 54.38 \%$, and $68.94 \%$, respectively, in ginseng seeds autoclaved at $130^{\circ} \mathrm{C}$ for $120 \mathrm{~min}$, which was the highest SOD activity. Overall, SOD activity was higher in autoclaved ginseng seeds than that in untreated ginseng seeds and showed a tendency to increase in a concentration-dependant manner. SOD activity was clearly higher as the autoclaving temperature increased. SOD-like activity in ginseng seeds showed a similar tendency to increase with autoclaving time and temperature as with DPPH radical scavenging activity, ABTS radical scavenging activity, and FRAP. Taken together, antioxidant activity of ginseng seeds generally increased as autoclaving time and temperature were increased.

\section{REFERENCES}

1. Ha DC, Ryu GH. Chemical components of red, white and extruded root ginseng. J Korean Soc Food Sci Nutr 2005;34:247-254.

2. Kong BR, Park MJ, Min JW, Kim HB, Kim SH, Kim SY, Yang DC. Physico-chemical characteristics of white, fermented and red ginseng extracts. J Ginseng Res 2008;32:238-243.

3. Ryu GH. Present status of red ginseng products and its 
manufacturing process. Food Ind Nutr 2003;8:38-42.

4. Hong HD, Park HJ, Jeong JK, Jang DJ. Surveys of domestic and foreign patents for process food related ginseng. J Ginseng Res 2008;32:135-149.

5. Im GY, Jang SY, Jeong YJ. Quality characteristics of Panax ginseng C. A. Meyer with steaming heat and wet grinding conditions. J Korean Soc Food Sci Nutr 2010;39:1005-1010.

6. Cho KL, Woo HJ, Lee IS, Lee JW, Cho YC, Lee IN, Chae HJ. Optimization of enzymatic pretreatment for the production of fermented ginseng using leaves, stem and roots of ginseng. J Ginseng Res 2010;34:68-75.

7. Lim SI, Cho CW, Choi UK, Kim YC. Antioxidant activity and ginsenoside pattern of fermented white ginseng. J Ginseng Res 2010;34:168-174.

8. Kim HJ, Lee SG, Chae IG, Kim MJ, Im NK, Yu MH, Lee EJ, Lee IS. Antioxidant effect of fermented red ginseng extracts in streptozotocin-induced diabetic rats. J Ginseng Res 2011;35:129-137.

9. Im GY, Jang SY, Jeong YJ. Quality characteristics of Panax ginseng C. A. Meyer with steaming heat and wet grinding conditions. J Korean Soc Food Sci Nutr 2010;39:1005-1010.

10. Kim CS, Jang DS, Che SY. Histological characteristics of Korean red ginseng in steaming processes. Korean J Med Crop Sci 2006;14:36-40.

11. Sung HS, Yang JW. Effect of the heating treatment on the stability of saponin in white ginseng. J Korean Soc Food Nutr 1986;15:22-26.

12. Yang SJ, Woo KS, Yoo JS, Kang TS, Noh YH, Lee JS, Jeong HS. Change of Korean ginseng components with high temperature and pressure treatment. Korean J Food Sci Technol 2006;38:521-525.

13. Hong HD, Kin YC, Rho JH, Kim KT, Lee YC. Changes on physicochemical properties of Panax ginseng C. A. Meyer during repeated steaming process. J Ginseng Res 2007;31:222-229.

14. Kim JK, Kim BY, Park CW, Seo DB, Yoo HR, Lee SJ. Effect of ginseng-berry extract on the improvement of blood microcirculation and skin brightness. Korean J Orient Physiol Pathol 2010;24:85-90.

15. Jeon JM, Choi SK, Kim YJ, Jang SJ, Cheon JW, Lee HS. Antioxidant and antiaging effect of ginseng berry extract fermented by lactic acid bacteria. J Soc Cosmet Sci Korea 2011;37:75-81.

16. Sugimoto S, Nakamura S, Matsuda H, Kitagawa N, Yoshikawa M. Chemical constituents from seeds of Panax ginseng: structure of new dammarane-type triterpene ketone, panaxadione, and hplc comparisons of seeds and flesh. Chem Pharm Bull (Tokyo) 2009;57:283-287.

17. Zue XM, Hu JN, Shin JA, Lee JH, Hong ST, Lee KT. Comparison of seed oil characteristics from Korean ginseng, Chinese ginseng (Panax ginseng C.A. Meyer) and American ginseng (Panax quinquefolium L.). J Food Sci Nutr 2010;15:275-281.

18. Beveridge TH, Li TS, Drover JC. Phytosterol content in American ginseng seed oil. J Agric Food Chem 2002;50:744-750.

19. Bark KM, Heo EP, Han KD, Kim MB, Lee ST, Gil EM, Kim TH. Evaluation of the phototoxic potential of plants used in oriental medicine. J Ethnopharmacol 2010;127:11-18.

20. Singleton VL, Rossi JA Jr. Colorimetry of total phenolics with phosphomolybdic-phosphotungstric acid reagents. Am J Enol Vitic 1965;16:144-158.

21. Blois MS. Antioxidant determination by the use of a stable free radical. Nature 1958;181:1199-1200.

22. Hassas-Roudsari M, Chang PR, Pegg RB, Tyler RT. Antioxidant capacity of bioactives extracted from canola meal by subcritical water, ethanol and hot water extraction. Food Chem 2009;114:717-726.

23. Van den Berg R, Haenen GR, van den Berg H, Bast A. Applicability of an improved Trolox equivalent antioxidant capacity (TEAC) assay for evaluation of antioxidant capacity measurements of mixtures. Food Chem 1999;66:511-517.

24. Lee JW, Lee SK, Do JH, Sung HS, Shim KH. Browning reaction of fresh ginseng (Panax ginseng C. A. Meyer) as affected by heating temperature. Korean J Ginseng Sci 1995;19:249-253.

25. Yang SJ, Woo KS, Yoo JS, Kang TS, Noh YH, Lee JS, Jeong HS. Change of Korean ginseng components with high temperature and pressure treatment. Korean J Food Sci Technol 2006;38:521-525.

26. Mensor LL, Menezes FS, Leitao GG, Reis AS, dos Santos TC, Coube CS, Leitao SG. Screening of Brazilian plant extracts for antioxidant activity by the use of DPPH free radical method. Phytother Res 2001;15:127-130.

27. Li H, Choi Y, Lee J, Park JS, Yeon KS, Han CD. Drying and antioxidant characteristics of the shiitake (Lentinus edodes) mushroom in a conveyer-type far-infrared dryer. J Korean Soc Food Sci Nutr 2007;36:250-254.

28. Kim HJ, Lee JY, You BR, Kim HR, Choi JE, Nam KY, Moon BD, Kim MR. Antioxidant activities of ethanol extracts from black ginseng prepared by steaming-drying cycles. J Korean Soc Food Sci Nutr 2011;40:156-162. 